\title{
FOOT RINGWORM IN COAL-MINERS*
}

\author{
BY \\ J. C. GENTLES and J. G. HOLMES \\ From the Department of Bacteriology, the University of Glasgow, and Department of Dermatology, \\ United Cardiff Hospitals
}

(RECEIVED FOR PUBLICATION JUNE 27, 1956)

Ringworm of the feet was first reported in Britain by Whitfield (1908). It leads to irritation and to various eczematous manifestations of and about the toes and sometimes elsewhere on the skin of the feet: the nails may also be affected. The common causative fungi are Trichophyton mentagrophytes, T. rubrum, and Epidermophyton floccosum. This paper describes an epidemiological study of the disease as it affects industrial workers, especially coal-miners.

By 1951 it was clear that ringworm was a troublesome complaint in coal-miners. A statistical study of compensation data carried out at the Headquarters of the National Coal Board had suggested that pithead baths were important factors. This fact was capable of several interpretations:(1) That baths favoured the spread of ringworm (Memmesheimer, 1936; Knowles, 1943; Adamson and Annan, 1949); (2) that bathing so altered the immunity of the host as to make infection with the parasite possible; (3) that bathing aggravated preexisting infection (Riddell, 1951); (4) that factors associated with bathing-hot working conditions in deep hot pits with baths-were the cause of the aggravation or change in the host-parasite relationship.

Apart from the site, nature, and condition of a man's employment, various factors common to mineworkers and non-mineworkers had also to be considered, namely, age and seasonal variation and geographical variation throughout the different

*This work was carried out under the direction of the Committee for Industrial Epidermophytosis of the Medical Research Council, Dr. J. T. Ingram (Chairman), Dr. J. B. Adamson (died June, 1955) Dr. G. C. Ainsworth, Dr. A. L. Cochrane, Dr. T. E. Howell (resigned owing to ill-health, 1953; died June, 1954), Professor G. H. Percival, Dr. D. D. Reid, Dr. J. M. Rogan, Dr. H. R. Vickers, Dr. B. S. Lush (Secretary). Reports to the Committee containing full details of the work have been deposited in the library of the National Institute for Medical Research, Mill Hill, N.W.7, and may be consulted on application. The clinical data formed part of a thesis by one of us (J. G. H.) and a précis of this paper was read by him at the Annual Meeting of the British Association of Dermatology in July, 1955. parts of Great Britain. It was decided that a field survey was the only way to obtain the information required.

\section{The Pilot Survey}

A pilot survey was carried out at Pit A, a colliery with baths. With the aid of tables (Kendall and Babington Smith, 1939) a random sample of 200 men was selected from the nominal rolls; 195 were examined.

As a result of this pilot study, we concluded: (1) That the men would respond readily, provided there was a system of appointments and the examination took no longer than five minutes; (2) that the methods used for clinical examination and laboratory diagnosis were satisfactory; (3) that body ringworm was rare and unimportant; (4) that foot ringworm was common. The clinical diagnosis was difficult, and laboratory confirmation was essential.

It was decided to limit further work to a study of foot ringworm only.

\section{The Survey Proper}

Method.-It was not possible to select the places for survey strictly at random, but it was arranged that a wide geographical area was covered. Visits were made to 11 pits, a training centre, and two power stations; the location of each is shown in Fig. 1.

In contrast to the selection of pits and power stations, the men were selected strictly at random as in the pilot study. Since separate nominal rolls were kept for men doing different work, it was possible to allot quotas to the various occupational groups and to increase the quotas of the groups which interested us most.

As far as possible the procedure at the interview was the same for each patient. After a standard history and clinical examination, at least one skin sample was taken from each foot. The only variations were (1) that help was sometimes available for 


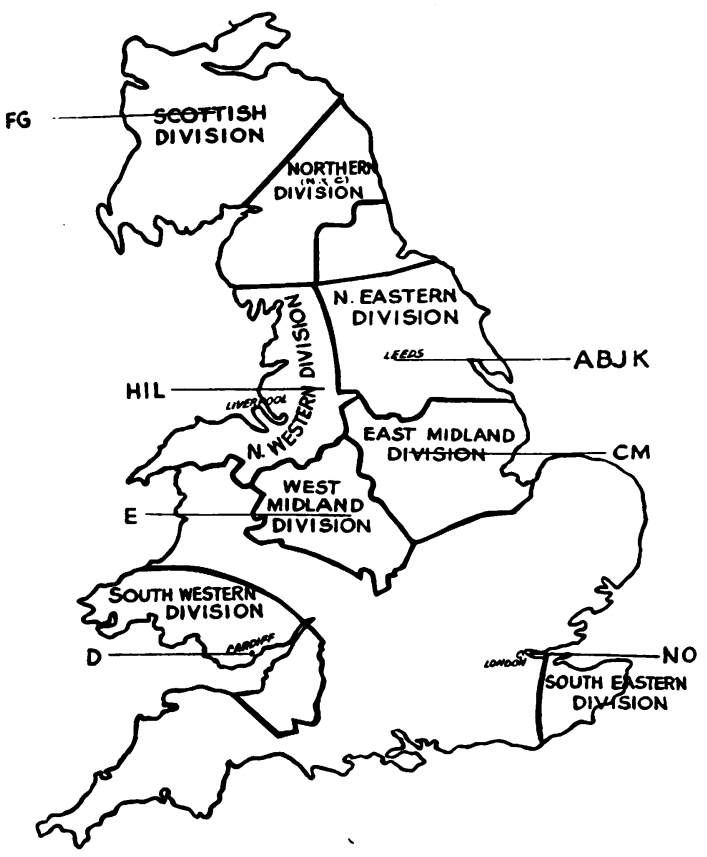

Fig. 1.-Location of places surveyed.

the taking of the history and (2) that additional skin and/or nail specimens were sometimes taken from men with suspicious lesions.

The skin and nail samples were posted to the mycologist in numbered slips of paper. He processed the day's specimens in any order and gave the same treatment to each. Twelve fragments each of about $1 \mathrm{~mm}$. in diameter were cultured on $4 \%$ malt extract agar at $28^{\circ} \mathrm{C}$ for three weeks; microscopic examination was made after clearing in $20 \% \mathrm{KOH}$. The origin of the material was not known in the laboratory until both microscopical and cultural results had been reported. Mosaic (Weidman, 1927) was not considered as evidence of infection.

\section{Results}

Response Rate. - Of the 2,160 men selected for examination, $2,101(97 \%)$ were seen-a very satisfactory response. Of the remaining $3 \%$, one-third refused and two-thirds were not available for unavoidable reasons, such as being in hospital. As far as could be ascertained, none of those off sick were suffering from a skin complaint.

Main Clinical and Laboratory Findings.-Ninety per cent $(1,900$ out of 2,101$)$ of the men examined had some clinical abnormality of the skin of the feet, which would have called for laboratory examination in routine clinical practice. By contrast the mycologist found only $21 \%$ (438) to be infected. As five of the infected men had feet which were clinically normal, the proportion of men with lesions who were proved to be infected was $23 \%$. (Details are given in a separate publication (Holmes and Gentles, 1956).)

Detailed Laboratory Findings.*-The number of men infected was $438(21 \%)$. The grounds for diagnosis of the 438 infected men were: culture and microscopy, 346, culture only, 57, microscopy only, 32, others, three (two Candida albicans and one doubtful). The cultural results were: $T$. mentagrophytes 224 (all but two of the interdigitale strain), $T$. rubrum 148, E. floccosum 11, T. mentagrophytes and $T$. rubrum 13, E. floccosum and T. rubrum 4, E. floccosum and T. mentagrophytes 3.

On the occasions when two dermatophytes were obtained from a patient they were isolated from the same lesion (combined infection) 11 times and nine times from different sites (concurrent infection). Whilst the overall species distribution was $T$. mentagrophytes $61 \%, T$. rubrum $35 \%$, and E. floccosum $4 \%$, in the multiple infections the proportions were $80 \%, 85 \%$, and $35 \%$ respectively. Hopkins, Hillegas, Ledin, Rebell, and Camp (1947) have noted this relatively high frequency of $E$. floccosum and Partridge (1955) discusses in detail the presence of $T$. rubrum in multiple infections.

\section{The Effect of Environment}

Geographical Variation.-The prevalence rates as proved by the laboratory findings varied from $3.5 \%$ to $50 \%$; at the same time there was some grouping (Table 1). The two pits in Scotland (F and $G$ ) had

TABLE 1

PREVALENCE RATES FOR INDIVIDUAL PLACES VISITED

\begin{tabular}{c|c|c}
\hline Place & $\begin{array}{c}\text { No. of } \\
\text { Observations }\end{array}$ & $\begin{array}{c}\text { \% with Positive } \\
\text { Laboratory Report }\end{array}$ \\
\hline B & 200 & $3 \cdot 5$ \\
C & 217 & 50 \\
D & 149 & 32 \\
E & 153 & 31 \\
F & 72 & 16 \\
G & 74 & 17 \\
H & 150 & 21 \\
J & 146 & 6 \\
K & 221 & 28 \\
L & 169 & 8 \\
M & 148 & 15 \\
N & 124 & 12 \\
O & 68 & 25 \\
B $^{1}$ & 62 & 26 \\
\hline Total & 148 & 10 \\
\hline
\end{tabular}

similar rates as had the two power stations in London ( $\mathrm{N}$ and $\mathrm{O}$ ), but other results could not te

*Cultures and herbarium specimens of the three species of dermatophytes have been deposited at the Centraal bureau voor Schimmelcultures, Baarn, and at the Mycological Reference Laboratory The London School of Hygiene and Tropical Medicine, W.C.1. 
explained on geographical grounds. Neighbouring places had widely different rates, e.g., C $50 \%$, $\mathrm{M} 12 \%$, and similar rates were obtained from different parts of the country, e.g., D $32 \%$, J $28 \%$. It was therefore necessary to look for other factors which might have been influencing the rates, viz., the presence of pit-head baths, conditions underground.

The General Effect of Communal Baths.-Four pits (I, K, L, M) had no pit-head baths; the prevalence rate ranged from $6 \%$ at $\mathrm{I}$ to $15 \%$ at $\mathrm{L}$. At the pits and power stations with baths $(\mathrm{C}, \mathrm{D}, \mathrm{E}$, $\mathrm{F}, \mathrm{G}, \mathrm{H}, \mathrm{J}, \mathrm{N}, \mathrm{O}$ ) the rates ranged from $16 \%$ at $\mathrm{F}$ to $50 \%$ at C. Pit B was visited twice-nine months before and six months after the completion of pithead baths; the rates were $3.5 \%$ and $10 \%$ respectively.

Not all the men at the pits with baths used them and at two pits without baths, $L$ and $M$, there were showers for officials.

In the tables that follow reference will be made to " bathers" and " non-bathers". " Bathers" denote men who either use or have used (if only very rarely) the baths at their present place of work, and " nonbathers " men who have never used the baths at their present place of work.

The prevalence rate for "bathers" was $31 \%$ (364 out of 1,153), and for " non-bathers" $8 \%(74$ out of 948). The cultural results for the former were: T. mentagrophytes $175, T$. rubrum 129, E. floccosum 7, C. albicans 1 , multiple infections 20 , and for the latter $T$. mentagrophytes $49, T$. rubrum $19, E$. floccosum $4, C$. albicans 1 , multiple infections 0 .

To see whether frequency of bathing was important, " bathers" were divided into three groups, namely, daily " bathers", weekly " bathers", and others. The prevalence rates were $33 \%, 35 \%$, and $21 \%$. The last group (approximately $12 \%$ of the total number of " bathers") was a composite one; it contained men who bathed as frequently as once a month and others who had not bathed for some years.

Nearly half the men examined gave a history of previous exposure. The prevalence rates were " bathers " with previous exposure $29 \%$ and without it $34 \%$, " non-bathers " with previous exposure $13 \%$ and without it $3 \%$. In Table 2 both " bathers" and "non-bathers" have been further subdivided according to whether they received their previous exposure in industry or the Forces or both. Previous exposure made little difference to the rates or species incidence for "bathers" but appeared very important for " non-bathers". As might be expected, of the " non-bathers" those with a history of double exposure had the highest rate, and then came men
TABLE 2

EFFECT OF PREVIOUS EXPOSURE

\begin{tabular}{|c|c|c|c|c|}
\hline \multirow{2}{*}{ Group } & \multicolumn{2}{|c|}{$\begin{array}{l}\text { Men with Service } \\
\text { in the } \\
\text { Forces }\end{array}$} & \multicolumn{2}{|c|}{$\begin{array}{l}\text { Men with No } \\
\text { Service in the } \\
\text { Forces }\end{array}$} \\
\hline & Number & $\begin{array}{c}\% \\
\text { Positive }\end{array}$ & Number & $\begin{array}{c}\% \\
\text { Positive }\end{array}$ \\
\hline $\begin{array}{l}\text { Bathers: } \\
\text { Men who have used other } \\
\text { industrial baths }\end{array}$ & 73 & 30 & 171 & 30 \\
\hline $\begin{array}{l}\text { Men who have not used } \\
\text { other industrial baths }\end{array}$ & 298 & 29 & 611 & 34 \\
\hline $\begin{array}{l}\text { Non-bathers: } \\
\text { Men who have used other } \\
\text { industrial baths }\end{array}$ & 52 & 23 & 170 & 17 \\
\hline $\begin{array}{l}\text { Men who have not used } \\
\text { other industrial baths }\end{array}$ & 231 & 10 & 495 & 3 \\
\hline
\end{tabular}

who had used other industrial baths; those who had been in the Forces gave a lower figure-perhaps because many men had served in the war of 191418 only-and last came men with no exposure in either the Forces or industry (Table 2).

The rates for the individual Services are given in Table 3; although the rates for ex-Naval men are

TABLE 3

EFFECT OF SERVICE IN THE FORCES

\begin{tabular}{|c|c|c|c|}
\hline & & Number & $\%$ Positive \\
\hline "Bathers" & $\begin{array}{l}\text { Royal Navy (including } \\
\text { Allied Navies) } \\
\text { Army } \\
\text { Royal Air Force } \\
\text { Others (including Merchant } \\
\text { Navy) }\end{array}$ & $\begin{array}{r}39 \\
288 \\
33 \\
11\end{array}$ & $\begin{array}{l}31 \\
28 \\
36 \\
36\end{array}$ \\
\hline "Non-bathers" & $\begin{array}{l}\text { Royal Navy (including } \\
\text { Allied Navies) } \\
\text { Army } \\
\text { Royal Air Force } \\
\text { Others (including Merchant } \\
\text { Navy) }\end{array}$ & $\begin{array}{r}32 \\
230 \\
16 \\
5\end{array}$ & $\begin{array}{r}34 \\
10 \\
6 \\
20\end{array}$ \\
\hline
\end{tabular}

the highest, the effect of Army service is more important since $80 \%$ of the ex-servicemen had been soldiers. Fraser (1939) noticed that sailors who had served abroad had higher rates than those who had stayed in home waters. We were unable to confirm this since only five of our ex-sailors had no foreign service, but our results for ex-army personnel show a similar trend. All who were non-bathers were divided into three groups: Those with service in the United Kingdom only (56 in all), those who had also served in Europe but not elsewhere overseas (91 in all), and those who had travelled farther afield (83 in all). The rates were $3.6 \%, 5.5 \%$, and $18 \%$ respectively.

Fourteen infected men gave no history of exposure in industry or in the Forces, but on special enquiry four of them said they used swimming baths. This leaves 10 men for whom the origin of infection remains obscure. 
Correlation of Clinical and Laboratory Findings.So far we have measured the effect of environmental factors by studying the laboratory results. The clinical findings are also of interest. The proportion of men with abnormal feet were as follows: "Bathers" with previous exposure $94 \%$, and without it $94 \%$; " non-bathers " with previous exposure $89 \%$, and without it $84 \%$. These four clinical rates are all much higher than the corresponding laboratory rates (see above). The correlation of the clinical and laboratory findings has been discussed (Holmes and Gentles, 1956), but it is important to note that whilst the clinical rates for all four groups were quantitatively similar, there were important qualitative differences between them. Thus the percentage of men with vesicular lesions increased from $2 \%$ for men with no history of exposure to $18 \%$ for " bathers".

Variation from Place to Place.-For " bathers" the prevalence rates varied from place to place and so did the cultural results (Table 4). The highest rate,

TABLE 4

PREVALENCE RATES AND CULTURAL RESULTS FOR BATHERS



$53 \%$, was at $\mathrm{C}$ and the lowest, $16 \%$, at $\mathrm{B}$ where the baths had only been open six months. The commonest species of dermatophyte was usually $T$. mentagrophytes; but at Pit C T. rubrum was far the commoner and at Pit $\mathrm{J}$ the incidence of the two species was almost equal. Over half the multiple infections occurred at these two pits; at $\mathbf{J}$ multiple infections formed $12 \%$ of the total positives. Pit $\mathrm{H}$ was unusual in that no case of $T$. rubrum infection was detected there.

The exact reason why the rate at Pit $\mathrm{C}$ was so high is not clear. Possibilities considered were the number of men employed, the age of the baths, the composition of the bath-house floor, the method of cleaning; it was decided that the most likely reason
TABLE 5

EFFECT OF PREVIOUS EXPOSURE ON CULTURAL RESULTS FOR BATHERS

\begin{tabular}{l|c|c|c|c|c|c}
\hline \multicolumn{1}{|c|}{ Place } & \multicolumn{2}{c}{$\begin{array}{c}\text { Men without History } \\
\text { of Previous Exposure }\end{array}$} & \multicolumn{2}{|c|}{$\begin{array}{c}\text { Men with History of } \\
\text { Previous Exposure }\end{array}$} \\
\cline { 2 - 7 } & $\begin{array}{c}\text { T. men- } \\
\text { tagro- } \\
\text { phytes }\end{array}$ & $\begin{array}{c}\text { T.ru- ru- } \\
\text { brum }\end{array}$ & $\begin{array}{c}\text { Total No } \\
\text { Examined }\end{array}$ & $\begin{array}{c}\text { T. men- } \\
\text { tagro- } \\
\text { phytes }\end{array}$ & $\begin{array}{c}\text { T. ru- } \\
\text { brum }\end{array}$ & $\begin{array}{c}\text { Total No. } \\
\text { Examined }\end{array}$ \\
\hline Pit C & 9 & 63 & 154 & 4 & 18 & 52 \\
Pit J \\
All others & 12 & 13 & 105 & 10 & 11 & 85 \\
\hline Total & 68 & 9 & 352 & 72 & 15 & 405 \\
\hline
\end{tabular}

Two most important species only, excluding multiple infections.

was the presence of $T$. rubrum as infections with this species are difficult to treat.

The effect of previous bathing is shown in Table 5 . There is no evidence that the epidemics of $T$. rubrum are due to differences in the men's past bathing history.

For " non-bathers" the variation in the species incidence and the cultural results are given in Table 6. It was found that much, if not all, of the

TABLE 6

PREVALENCE RATES AND CULTURAL RESULTS FOR NON-BATHERS

\begin{tabular}{|c|c|c|c|c|c|c|c|}
\hline Place & $\begin{array}{l}\text { Total } \\
\text { No. of } \\
\text { Non- } \\
\text { bathers }\end{array}$ & $\begin{array}{l}\text { Posi- } \\
\text { tive }\end{array}$ & $\begin{array}{l}\text { Micro- } \\
\text { scopic- } \\
\text { ally } \\
\text { Positive }\end{array}$ & $\begin{array}{l}T . \text { men- } \\
\text { tagro- } \\
\text { phytes }\end{array}$ & $\begin{array}{c}T . \\
\text { rubrum }\end{array}$ & $\begin{array}{l}\text { E. floc- } \\
\text { cosum }\end{array}$ & $\begin{array}{c}\text { Two } \\
\text { Species }\end{array}$ \\
\hline $\begin{array}{l}\mathbf{B} \\
\mathbf{C} \\
\mathbf{D} \\
\mathbf{E} \\
\mathbf{F} \\
\mathbf{G} \\
\mathbf{H} \\
\mathbf{I} \\
\mathbf{J} \\
\mathbf{K} \\
\mathbf{L} \\
\mathbf{M} \\
\mathbf{N} \\
\mathbf{O} \\
\mathbf{B}^{1}\end{array}$ & $\begin{array}{r}200 \\
11 \\
14 \\
24 \\
10 \\
5 \\
7 \\
146 \\
31 \\
169 \\
142 \\
100 \\
16 \\
20 \\
53\end{array}$ & $\begin{array}{c}3 \cdot 5 \\
9 \\
4 \\
10 \\
\frac{4}{7} \\
6 \\
10 \\
8 \\
15 \\
11 \\
19 \\
15 \\
-\end{array}$ & $\begin{array}{l}\overline{1} \\
\bar{z} \\
\overline{\bar{I}} \\
\overline{1}^{*} \\
\bar{z} \\
\bar{z} \\
\bar{z}\end{array}$ & $\begin{array}{r}\frac{5}{7} \\
1 \\
\frac{1}{7} \\
6 \\
3 \\
12 \\
11 \\
6 \\
2 \\
2 \\
-\end{array}$ & $\begin{array}{l}1 \\
= \\
= \\
= \\
\frac{1}{2} \\
10 \\
3 \\
1 \\
1 \\
-\end{array}$ & $\begin{array}{l}\frac{1}{二} \\
= \\
\overline{1} \\
\frac{1}{z} \\
\frac{2}{2} \\
=\end{array}$ & $\begin{array}{l}= \\
= \\
= \\
= \\
= \\
= \\
=\end{array}$ \\
\hline Total & 948 & 8 & 2 & 49 & 19 & 4 & - \\
\hline
\end{tabular}

variation in the prevalence rates depended on the opportunities for infection in industry; the effect of service in the Forces was more evenly distributed. Figures obtained at Pits $L$ and $B$ will be used to illustrate this point, for, excluding small groups, these pits had the highest and the lowest rates respectively. $L$ was a pit situated in a town and it was near baths built as long ago as 1913. Of the 142 " non-bathers" examined at this pit, 52 gave a history of using pit-head baths previously and 14 of them were infected. B was a pit in the country and it had no neighbouring baths before 1949. Only 15 men out of 200 had used pit-head baths and none were infected. Further details are given in Table 7. 
TABLE 7

FURTHER EVIDENCE OF EFFECT OF PREVIOUS EXPOSURE ON RATES FOR NON-BATHERS

\begin{tabular}{|c|c|c|c|c|c|c|c|c|}
\hline \multirow[t]{2}{*}{ Laboratory Report } & \multicolumn{2}{|c|}{$\begin{array}{l}\text { Men with Double } \\
\text { Exposure in Industry } \\
\text { and Forces }\end{array}$} & \multicolumn{2}{|c|}{$\begin{array}{c}\text { Men Previously } \\
\text { Exposed in Industry } \\
\text { Alone }\end{array}$} & \multicolumn{2}{|c|}{$\begin{array}{l}\text { Men Previously } \\
\text { Exposed in Forces } \\
\text { Alone }\end{array}$} & \multicolumn{2}{|c|}{$\begin{array}{c}\text { Men with no } \\
\text { Known Exposure }\end{array}$} \\
\hline & Positive & Negative & Positive & Negative & Positive & Negative & Positive & Negative \\
\hline $\begin{array}{l}\text { Pit } \\
\text { Pit } \text { B }\end{array}$ & $\begin{array}{l}6 \\
0\end{array}$ & $\begin{array}{r}12 \\
6\end{array}$ & $\begin{array}{l}8 \\
0\end{array}$ & $\begin{array}{r}26 \\
9\end{array}$ & $\begin{array}{l}2 \\
6\end{array}$ & $\begin{array}{l}29 \\
59\end{array}$ & $\begin{array}{l}5^{* *} \\
1\end{array}$ & $\begin{array}{r}54 \\
120\end{array}$ \\
\hline
\end{tabular}

*One infected man known to use swimming baths.

As for "bathers" the commonest species was $T$. mentagrophytes. Forty-nine men were infected with this species; 40 of them had a history of exposure (two as swimmers). Only four men were infected with E. floccosum; three gave a history of exposure. There were no multiple infections. All the 19 men who were infected with $T$. rubrum gave a history of exposure (two as swimmers). It was noted that 10 men with this species came from Pit $\mathrm{L}$, where they formed $48 \%$ of the total number infected; elsewhere the proportion was $17 \%$. There were no cases of T. rubrum infection from the 42 "non-bathers" at $\mathrm{C}$ and $\mathrm{J}$, the two pits where this species was common in " bathers". We suggest that the high incidence at $\mathrm{L}$ is due in part to $T$. rubrum being endemic at a neighbouring colliery or collieries for eight out of the 10 men had used pit-head baths.

Method of Spread of Infection.-Gray (1911) and Sanderson and Sloper (1953) have referred to crossinfection via infected clothing. From general inquiries we believe that few of the men in our survey shared clothing, and if this is true then clothing cannot be important for our population. The main criticism of the other theory that infection is spread - via the floors is the failure of the vast majority of attempts to isolate dermatophytes from them. Peck, Botvinick, and Schwartz (1944) made over 60 attempts and concluded from their negative results that either the fungi were not widely disseminated on floors, or they were washed down the drains too quickly to make isolation possible by the procedure used. So far as we are aware there are only two detailed reports of isolation of dermatophytes from floors. Adamson and Annan (1949) isolated T. mentagrophytes from a piece of skin found on the floor of a bath-house, and Ajello and Getz (1954) isolated the same species from a shower floor of a penitentiary in the U.S.A. Using a direct sampling method* we have been successful in isolating $T$. mentagrophytes from the floors of showers of three pit-head baths, the dressing-room of an athletic ground, and a public swimming bath. $T$. rubrum, which was the fungus present in over

\footnotetext{
*The essential of the method is the use of a velvet pad on a wooden stamp. Full details are given in a separate publication (Gentles, 1956).
}

$80 \%$ of positive cases at Pit $\mathrm{C}$, was isolated from the showers there.

Source of Infection in a New Bath-house.-The original sources of infection are multiple. After Dunkirk many baths, including $\mathrm{C}$, were used by army units; nowadays infection is probably introduced mainly by ex-servicemen as individuals and by men from other pit-head baths. On the return visit to B it was found that men with a history of previous exposure were the first to use the baths, the others being more cautious. Moreover, it so happened that some men were included in both samples and all those originally proved to be infected were bathing. "Non-bathers" at this visit formed the only large group free of infection which also suggests that there had been some selection.

\section{Seasonal Variation}

Sanderson and Sloper (1953) have discussed seasonal variation under tropical conditions.

One pit with baths (C) was visited on three occasions, in March, June, and December, 1953. The infection rates for " bathers" were 50,55 , and $55 \%$ respectively. No one pit without baths was visited twice, but the visit to B was in February, to $M$ in June, and to $I$ in November. The return visit to B took place in 1954. No evidence of seasonal variation was detected; however, it should be mentioned that the predominant species at Pit $\mathrm{C}$ was T. rubrum and seasonal variation was not studied at a pit with baths when the predominant species was $T$. mentagrophytes.

\section{Age}

Men were divided into six age groups (Table 8). The rate for the lowest age-group (15-24) was $15 \%$ and for the highest age-group (65+) $17 \%$; there was a peak rate of $25 \%$ at ages $35-44$. When the men were divided up according to their bathing habits it was found that there was no real pattern to the rates for "non-bathers", whilst that for " bathers" reached a flat level at age 45 and did not fall as the men grew older. The apparent fall with increasing age seen in the crude rates was due to the high number of "non-bathers" without exposure in the older age group. 
TABLE 8

THE EFFECT OF AGE

\begin{tabular}{|c|c|c|c|c|c|c|c|c|}
\hline \multirow{2}{*}{ Age in Years } & \multicolumn{2}{|c|}{ Total } & \multicolumn{2}{|c|}{ All Bathers } & \multicolumn{2}{|c|}{$\begin{array}{l}\text { Non-bathers with } \\
\text { Previous Exposure }\end{array}$} & \multicolumn{2}{|c|}{$\begin{array}{l}\text { Non-bathers without } \\
\text { Previous Exposure }\end{array}$} \\
\hline & Number & $\%$ Positive & Number & $\%$ Positive & Number & $\%$ Positive & Number & $\%$ Positive \\
\hline $\begin{array}{l}15-24 \\
25-34 \\
35-44 \\
45-54 \\
55-64 \\
65+\end{array}$ & $\begin{array}{r}451 \\
419 \\
389 \\
521 \\
262 \\
59\end{array}$ & $\begin{array}{l}15 \\
22 \\
25 \\
23 \\
22 \\
17\end{array}$ & $\begin{array}{r}194 \\
261 \\
244 \\
306 \\
121 \\
27\end{array}$ & $\begin{array}{l}25 \\
28 \\
32 \\
36 \\
38 \\
37\end{array}$ & $\begin{array}{r}113 \\
109 \\
74 \\
67 \\
84 \\
6\end{array}$ & $\begin{array}{r}12 \\
15 \\
19 \\
12 \\
10 \\
0\end{array}$ & $\begin{array}{c}144 * * * \\
49 \\
71 * \\
148 \\
57 \\
26\end{array}$ & $\begin{array}{l}4 \\
4 \\
6 \\
1 \\
2 \\
0\end{array}$ \\
\hline
\end{tabular}

*One infected man known to use swimming baths.

\section{Duration of Present Employment}

Men were divided into six groups. As with age there was a peak rate for the middle groups, but it was less marked. Allowances were made for bathing; once again there was no pattern for " nonbathers" whilst that for " bathers" reached a flat level at the six- to ten-year period. (Further details are given in the report to the M.R.C. Committee.)

On more detailed analysis it was found that for bathers with under one year's service and without previous exposure the rate was $7 \%$, but for a similar group with previous exposure the rate was $23 \%$. Admittedly, duration of employment is only a rough measure of the time over which the men had used baths, but this apparent lag in the increase of infection has been noticed by other workers (Vanbreuseghem, Peeters, and Tritsmans, 1952). It is consistent with the experimental work of Baer, Rosenthal, Rogachefsky, and Litt (1955) who found it difficult to infect human volunteers. However, this lag is not universal for there was a notable increase in the prevalence rate at Pit B within six months of the installation of baths. At the first visit the rate was $3.5 \%$, and at the second visit it was $10 \%$, or $16 \%$ (15 of 95$)$ for " bathers" and $0 \%(0$ of 53$)$ for "non-bathers". Even when allowances are made for the tendency at this colliery for men with a previous history of exposure to use the baths and for men without such a history to refrain, the rise is still appreciable-probably not less than $10 \%$ from 6 to $16 \%$.

Factors Peculiar to Mineworkers

Site of Work.-Carrié and Zantopf (1941) report a higher rate for underground workers than for surface workers. No comparison can be drawn as the bathing habits of the men were not given, nor were any details given of the conditions underground. Our rate for underground workers and for surface workers who had worked underground was $23 \%$ (369 out of 1,588), while for surface workers who had never been underground it was only $12 \%$ ( 22 out of 214). Much, but not all, of this difference could be attributed to their bathing history (Table 9) and to the fact that surface workers who had never been underground were often new entrants to the industry. Perhaps the feet of underground workers are more subject to minor trauma, which Kligman (1952) has shown to be important; or perhaps the surface worker who has never been underground may be more cautious and take greater care of his feet.

Nature of Work.-The number of surface workers was too small to be subdivided. The nature of employment underground appeared to be unimportant. (Details are given in the report to the M.R.C. Committee.)

Temperature Underground.-Three pits with baths (D, E, and J) had one seam distinctly hotter than the others. The hottest seam was at $J$, where a reading of $75^{\circ} \mathrm{F}$. (wet bulb) was obtained with a whirling hygrometer. It appeared unlikely that the temperature affected the rates very much: however, the number of men involved was rather small.

The effect of working in a hot seam on the rates for "non-bathers" was to have been studied at Pit L. Unfortunately the hot seam was closed by - the time we carried out our investigation.

Few pits in Great Britain have temperatures much higher than $75^{\circ} \mathrm{F}$. (wet bulb) and when they do, the

TABLE 9

EFFECT OF SITE OF WORK

\begin{tabular}{|c|c|c|c|c|c|c|c|}
\hline \multicolumn{2}{|l|}{ Site of Work } & \multicolumn{2}{|c|}{ Bathers } & \multicolumn{2}{|c|}{$\begin{array}{c}\text { Non-bathers" with } \\
\text { Exposure }\end{array}$} & \multicolumn{2}{|c|}{$\begin{array}{l}\text { "Non-bathers" without } \\
\text { Exposure }\end{array}$} \\
\hline & & Total & $\%$ Positive & Total & $\%$ Positive & Total & $\%$ Positive \\
\hline $\begin{array}{l}\text { (1) Underground } \\
\text { (2) Surface previously underground } \\
\text { (1) }+(2)+\text { others } \\
\text { Surface never worked underground }\end{array}$ & $\begin{array}{l}\cdots \\
\cdots \\
\cdots\end{array}$ & $\begin{array}{r}889 \\
77 \\
975 \\
84\end{array}$ & $\begin{array}{l}32 \\
34 \\
33 \\
24\end{array}$ & $\begin{array}{r}229 \\
51 \\
282 \\
44\end{array}$ & $\begin{array}{r}14 \\
12 \\
14 \\
5\end{array}$ & $\begin{array}{r}256 \\
65 \\
331 \\
86\end{array}$ & $\begin{array}{l}4 \\
1 \\
4 \\
0\end{array}$ \\
\hline
\end{tabular}


TABLE 10

EFFECT OF WORKING IN HOT SEAMS ON REGULAR BATHERS

\begin{tabular}{|c|c|c|c|c|c|c|c|c|}
\hline \multirow[t]{2}{*}{ Place } & \multicolumn{2}{|c|}{ All Regular Bathers } & \multicolumn{2}{|c|}{ Surface Workers } & \multicolumn{2}{|c|}{ Workers in Hot Seams } & \multicolumn{2}{|c|}{ Workers in Other Seams } \\
\hline & Total & $\%$ Positive & Total & $\%$ Positive & Total & $\%$ Positive & Total & $\%$ Positive \\
\hline $\begin{array}{l}\text { Pit J } \\
\text { Pit } \\
\text { Pit } \\
\text { E }\end{array}$ & $\begin{array}{r}151 \\
121 \\
97\end{array}$ & $\begin{array}{l}34 \\
35 \\
43\end{array}$ & $\begin{array}{r}27 \\
13 \\
8\end{array}$ & $\begin{array}{l}33 \\
46 \\
50\end{array}$ & $\begin{array}{l}57 \\
18 \\
26\end{array}$ & $\begin{array}{l}37 \\
44 \\
42\end{array}$ & $\begin{array}{l}62 \\
71 \\
50\end{array}$ & $\begin{array}{l}34 \\
28 \\
40\end{array}$ \\
\hline
\end{tabular}

maximum temperature is usually confined to one district or even part of a district (McLintock, 1954).

\section{Inconvenience and Disability}

No men examined by us were off work primarily for a skin complaint, but $2 \%$ gave a history of having lost time due to conditions diagnosed as foot ringworm by their own doctors. At two pits several men had stopped using the baths because they had had sore feet or else because they did not wish to become infected.

Apart from this, few men would state that they knew anything was wrong with their feet, possibly because to have done so would have been to admit that they should have been receiving treatment. Only 36 men were having treatment at the time they were examined; 16 of them were found to be infected. This is important because treatment might have led to the masking of infection and our failure to isolate fungus from clinically suspicious lesions.

\section{Follow-up Examination}

Pit C was visited in March, June, and December of 1953. We returned in November, 1954, to re-examine 100 of the regular bathers. The results for $80 \%$ of the men remained unchanged, 46 being infected both times and 34 being apparently free from infection both times. Ten men were positive the first time only and nine men were positive the second time only. One man could not be seen the second time. This makes a total of 65 infected at one time or another, 55 of them with T. rubrum.

From a study of the clinical findings it appeared (1) that some of the men found to be infected once only were really infected both times, (2) that some. men had got better whilst others had become infected during this period. Four out of the five men who had got better were originally suffering from an infection with $T$. mentagrophytes and only one from an infection with $T$. rubrum.

\section{Discussion}

Our survey has dealt with specific groups of industrial workers in Great Britain but we believe the results are capable of more general application and therefore the discussion will not be confined to the problems of ringworm in these groups.
In most published reports on the incidence of foot ringworm there is a discrepancy between the number of men with clinically abnormal feet and the number proved to be infected on laboratory examination. Early workers, e.g., Morris (1911), believed that this was because our laboratory methods were insufficiently sensitive and that if better techniques were available proof of infection would be obtained in the majority of such cases. For a time, from 1927 till 1936, when the finding of the mosaic fungus (Weidman, 1927) was accepted as evidence of infection, they appeared to be right. However, it is now generally agreed that mosaic is an artefact (Goldsmith and Hellier, 1954). The question of almost universal infection is therefore still being debated. Whilst some workers, e.g., Linn and Magarey (1941), consider that most cases of ringworm can be diagnosed readily by methods such as we have used, others consider there are many minimal infections that are missed. It should be noted in this connexion that whenever possible we re-examined surplus material from men who had suspicious lesions but who were not proved to be infected; only one extra positive case was proved in this way. (Report to the M.R.C. Committee.)

Sulzberger and Baer (1955) believe that foot ringworm is not transmissible in the ordinary sense. They argue that dermatophytes are ubiquitous, that we are all infected from time to time, and that whether or not we suffer from foot ringworm depends on personal immunity. We agree that personal immunity is important but we disagree over the other points. There is no evidence that dermatophytes are ubiquitous in sufficient quantity to cause infection except perhaps in certain specialized places such as the floors of communal bath-houses. There is, moreover, good evidence that cross infection not only occurs but is the most important factor. Our reasons for holding this belief are as follows:-

Evidence from the Study of Non-bathers.-(a) Our low rates are similar to those of other workers (Phillips, 1944; Walker, 1950; Amrein, 1953). (b) It is implicit in the theory of universal infection that the effect of previous exposure should be short lived. This was not our experience. (c) Many of our "non-bathers" bathed daily at home; it is 
difficult to see why only communal bathing should lead to a breakdown in immunity.

Evidence from the Study of Bathers.-(a) The variation in the prevalence rates and in the species distribution, in particular the high rate of $T$. rubrum at $\mathrm{Pit} \mathrm{C}$ and its absence at $\mathrm{Pit} \mathbf{H}$, are greater than one would expect if exposure were unimportant and the effect of bathing were non-specific. It was the absence of a noticeable difference in the species incidence that led Hopkins et al. (1947) to support Sulzberger's views. (b) Dermatophytes were cultured from the floors of four bath-houses and on each occasion the species cultured corresponded to that found on the majority of men using the bath-houses. (c) It may apparently take months of regular daily bathing to cause infection, $c f$., Vanbreuseghem et al. (1952) and the experimental work of Baer et al. (1955). This suggests that both heavy exposure and a breakdown in personal immunity are necessary at one and the same time. (d) The absence of seasonal variation and the results of the follow-up examination at Pit $C$ suggest that once a man is infected either the infection remains detectable or else he rids himself of infection completely.

Multiple Infections.- No multiple infections were detected in 74 infected "non-bathers" but there were 20 cases among the 364 infected "bathers". The highest incidence of these infections $(13.7 \%$ of infected bathers) was at Pit $\mathbf{J}$ where there was an almost equal number of men infected with one or other of the major species.

\section{Summary and Conclusions}

An epidemiological survey of foot ringworm was conducted in different parts of Great Britain and in communities some of which did and some of which did not have communal baths. Most, but not all, of the men examined worked in the coal-mining industry. Comparisons of the clinical findings and mycological infection rates between the various groups of men suggested that, although previous exposure and working conditions were related to the prevalence of infection, the habitual use of communal baths was the most important factor. The distribution of the dermatophyte species varied from place to place, and on four occasions when a dermatophyte was isolated from the floor of a bath- house the species corresponded to that occurring most commonly in the men who were using it. These findings are discussed in relation to the hypothesis concerning the spread of foot ringworm.

It is concluded (1) that fungus infections of the feet are not universal; (2) that a specific exposure and a breakdown in personal immunity are necessary for infection to occur; (3) that in Great Britain these conditions occur together most commonly in those who use communal baths; (4) that in this country, other factors such as age, seasonal variation, and conditions of employment are of minor importance.

We wish to thank the medical services, the managements, and the men of the National Coal Board and the British Electricity Authority for their cooperation.

Sincere thanks are also expressed to the staff of the department of MedicalStatistics and Epidemiology, the London School of Hygiene and Tropical Medicine; the University of Glasgow and Professor John Walton, who provided laboratory accommodation; the University of Leeds for library facilities; Miss C. O. Dawson, Department of Bacteriology, the University of Glasgow; the medical artist of the Department of Pathology, the Welsh National School of Medicine; and the many colleagues who have discussed our problem with us.

\section{REFERENCES}

Adamson, J. B., and Annan, W. G. (1949). Brit. J. phys. Med., n.s., 12,34 .

Ajello, L., and Getz, M. E. (1954). J. invest. Derm., 22, 17.

Amrein, H. P. (1953). Praxis, 42, 197.

Baer, R. L., Rosenthal, S. A., Rogachefsky, H., and Litt, J. Z. (1955) Amer. J. Publ. Hlth, 45, 784.

Carrie, C., and Zantopf, H. (1941). Derm. Wschr., 112, 315.

Fraser, P. K. (1939). J. trop. Med. Hyg., 42, 141.

Gentles, J. C. (1956). J. clin. Path., 9, 374.

Goldsmith, W. N., and Hellier, F. F. (1954). Recent Advances in Dermatology, 2nd ed., p. 280. Churchill, London.

Gray, A. M. H. (1911). Brit. J. Derm., 23, 400 .

Holmes, J. G., and Gentles, J. C. (1956). Lancet, 2, 62. Hopkins, J. G., Hillegas, A. B., Ledin, R. B., Rebell, G. C., and

Kendall, M. G., and Smith, B. Babington (1939). Tables of Random Sampling Numbers. Univ. Press, Cambridge.

Kligman, A. M. (1952). J. invest. Derm. 18, 231.

Knowles, R. B. (1943). Dermatitis in Coal Miners, p. 10. M. D. Thesis, Sheffield.

Linn, L. W., and Magarey, F. R. (1941). Med. J. Aust., 2, 452.

Memmesheimer, A. M. (1936). Klin. Wschr., 15, 206.

Morris, M. (1911). Brit. J. Derm., 23, 400.

McLintock, J. S. (1954). Personal communication.

Partridge, B. M. (1955). Trans. St. John's Hosp. Derm. Soc., No. 34,

p. 41.

S. M., Botvinick, I., and Schwartz, L. (1944) Arch. Derm. Syph.'(Chicago), 50, 170.

Phillips, B. (1944). Brit. J. Derm., 56, 219.

Riddell, R. W. (1951). Brit. med. Bull., 7, 197.

Sanderson, P. H., and Sloper, J. C. (1953). Brit. J. Derm., 65, 252

Sulzberger, M. B., and Baer, R. L. (1955). Yearbook of Dermatology and Syphilology, 1954-55, p. 9 . Chicago.

Vanbreuseghem, R., Peeters, P., and Tritsmans, E. (1952). Arch. belg. Derm. Syph., 8, 343.
.

Walker, J. (1950). Brit. J. Derm., 62, 239.

Weidman, F. D. (1927). Arch. Derm. Syph. (Chicago), 15, 415.

Whitfield, A. (1908). Lancet, 2, 237. 